\title{
The Effectiveness of the Application of Mathematical Software in Indonesia; A Meta-Analysis Study
}

\author{
Maximus Tamur \\ M.Ed., Indonesia University of Education, Indonesia, maximustamur@upi.edu, \\ maximustamur@unikastpaulus.ac.id \\ Dadang Juandi \\ Dr., Indonesia University of Education, Indonesia, dadang.juandi@upi.edu

\section{Yaya Sukjaya Kusumah} \\ Prof., Indonesia University of Education, Indonesia, yayaskusumah@yahoo.com
}

This study aims to investigate the effectiveness of the application of mathematical software to the mathematical abilities of students in Indonesia. For this purpose, 64 effect sizes from 51 studies published in national and international journals from 2011 to 2019 were analyzed using the meta-analysis method. Comprehensive Meta-Analysis (CMA) software is used to assist the analysis. Hedges's g coefficient was used when the effect sizes were calculated and the confidence level was accepted as $95 \%$. As a result of the study, the overall effect size was 1.162 , with a standard error of 0.091 according to the random-effects model. These results indicate that the average student who is ranked 13th in the experimental group is equivalent to those who are ranked 4th in the control group. The study was conducted by considering four characteristics, producing a significant difference in terms of the year when the study was conducted and the type of software used. Thus the use of mathematical software produces a larger effect on mathematical ability than conventional approaches.

Keywords: mathematical software, meta-analysis, mathematical, ability, education

\section{INTRODUCTION}

The use of computer technology in the field of teaching as a tool for teaching and learning is becoming more widespread (Tomić, 2013; Sivakova, Kochoska, Ristevska, \& Gramatkovski, 2017). The use of computer technology can strengthen the learning process of students by presenting content numerically, graphically, and symbolically without the added burden of spending time calculating complex computing problems manually (Kilicman, Hassan, \& Husain, 2010). Computer-aided learning is the key to

Citation: Tamur, M., Juandi, D., \& Kusumah, Y. S. (2020). The Effectiveness of the Application of Mathematical Software in Indonesia; A Meta-Analysis Study. International Journal of Instruction, 13(4), 867-884. https://doi.org/10.29333/iji.2020.13453a 
increasing the effectiveness and quality of the education system (Berežný, 2015; Cingi, 2013).

Integrating computer technology into mathematics learning will help students to make connections in mathematics, by making the learning process more realistic and effective (Hartsell, Herron, Fang, \& Rathod, 2009; Horton, Storm, \& Leonard, 2004; Lavicza, 2010; Saha, Job, \& Tarmizi, 2010). Learning that integrates computers has the potential to positively influence the teaching and learning of mathematics at various levels of education (Artigue, 2002; Colado, Vázquez, \& Patrón, 2017; Pierce \& Stacey, 2004; Karakuş \& Aydin, 2017).

Mathematical software is a part of computer technology in learning mathematics. Learning using mathematical software will be more interesting, inventive, and exploratory (Aungamuthu, 2013; Foster, Anthony, Clements, \& Sarama, 2016; Ochkov \& Bogomolova, 2015). These conditions enable students to be more active and successful in learning (Timmers, Broek, \& Berg, 2013; (Kumar \& Kumaresan, 2008; Shadaan \& Leong, 2016; Tatar, 2013; Yesilyurt, Dogan, \& Acar, 2019).

In Indonesia, from 2011 to 2019 , there have been many studies on the effect of mathematical software applications at various levels of Education. Findings from the study are varied. Several studies (e.g., Jelatu et al., 2018; Nuraeni \& Rosyid, 2019; Siswanto \& Kusumah, 2017; Supriadi, Kusumah, Sabandar \& Afgani, 2014) report that the use of mathematical software has a significant influence on students' mathematical abilities. However, several other studies conducted by (Herawati, Studies, Mathematics, \& Siliwangi, 2017; Ramadhani, 2017; Setyani, 2016) report that the use of mathematical software in learning is influential, but not significant. On the other hand, the government and other related parties need accurate information about how the influence of the use of mathematical software in learning is to evaluate the implementation of the curriculum and the education system.

The above problems can be solved by conducting a study of combining various quantitative findings. The comparative use of quantitative conclusions provides useful information for practice or policy (Higgins \& Katsipataki, 2015). However, until 2019 in the literature, there has been no research combining the findings obtained in various studies. A literature review of just a few studies allows variations in results. On the other hand, literature reviews must provide comprehensive and in-depth conclusions (Kulik, Bangert, \& Williams, 1983; Randolph, 2009; Siddaway, Wood, \& Hedges, 2019).

Meta-analysis is seen as an objective method of literature review because it uses effect sizes. This procedure ignores subjective interpretations of diverse research reviews on the same topic or method (Borenstein \& Hedges, 2009; Hunter \& Schmidt, 2004). The meta-analysis is to collect study results consistently and appropriately (Hedges \& Olkin, 1985; Cohen J, 1988). Operationally meta-analysis is a quantitative technique that uses specific steps (for example, effect sizes) to show the strength of variable relationships for studies included in the analysis (Cleophas \& Zwinderman, 2017; Schwarzer, Carpenter, \& Rücker, 2015; Shelby \& Vaske, 2008). 
International studies conducted by (Chan and Leung, 2014; Higgins, Huscroft-D'Angelo, \& Crawford, 2019; Turgut \& Dogan Temur, 2017; Turgut \& Turgut, 2018) namely comparing the effect of the use of media and mathematical software on students' mathematical achievements using meta-analysis methods. However, not all mathematical software is used in the analysis. In Indonesia, only Tumangkeng, Yusmin, and Hartoyo (2018) conducted a meta-analysis of the effect of instructional media on mathematics learning outcomes. But the study search is only limited to the Pontianak Tanjungpura university library. There is no specific study on the meta-analysis of the effectiveness of mathematical software applications on mathematical abilities in Indonesia. As a result, the general picture of how the effect of applying mathematical software as a whole or in terms of various study characteristics such as the year of research, sample size, research class, and the software used has not been investigated.

This explanation shows the importance of conducting a comprehensive meta-analysis of the effectiveness of the use of mathematical software for the mathematical abilities of students in Indonesia from 2011 to 2019 . This is necessary to evaluate their use and see the overall trends clearly. Thisunderlies researchers to investigate the effect of using mathematical software on the mathematical abilities of students in Indonesia with the help of meta-analysis methods. In this context, this study examines the following questions:

1. Does the use of mathematical software produce a greater effect size than the conventional mathematical approach?

2. Does the measure of the effect of mathematical ability from the use of mathematical software between different study groups reviewed from the year of the study?

3. Does the effect size of the mathematical ability from the use of mathematical software between different study groups in terms of the research class?

4. Does the effect size of the mathematical ability to use mathematical software between different study groups in terms of sample size?

Does the effect size of the mathematical ability to use mathematical software between different study groups in terms of the type of software used?

\section{METHOD}

\section{Research Design}

This study aims to combine and statistically evaluate the findings of independent studies examining the application of mathematical software to the mathematical abilities of students in Indonesia. The meta-analysis method was used in this study. Meta-analysis provides an overall evaluation with statistical analysis of quantitative data obtained in independent studies on specific subjects (Cleophas \& Zwinderman, 2017; Glass, 1976; Schwarzer, Carpenter \& Rücker, 2015, Shelby \& Vaske, 2008). Effect size is a simple way to measure differences between two groups that have many advantages compared to using statistical significance tests alone (Coe, 2002; Ellis, 2010; Thalheimer \& Cook, 2002). A meta-analysis study is carried out by following the steps; First, identify the problem. Then search literature related to the problem. Studies achieved in the literature are coded according to specific criteria. After this stage, a statistical analysis of the 
research is carried out, and findings are interpreted (Borenstein \& Hedges, 2009; Pigott, 2012). This stage was also carried out in this study.

\section{Literature Search}

Studies included in the analysis were found using electronic databases, namely the Educational Resources Information Center (ERIC), IEJME, Springer, and Elsevier. Furthermore, to reach Indonesian language search articles, use the GOOGLE SCHOLAR and PORTAL GARUDA search engines. In this research, studies collected using the search engine from various reputable international journals, namely the International Electronic Journal of Mathematics Education (IEJME), International Journal of Instruction (IJI), Journal of Education and Practice (JEP), Journal of Mathematics Education ( JME) and Journal of Technology and Science Education (JOTSE). In addition, national journals were also obtained, namely the Mathematics Education Research Journal (JPM), the Mathematical Didactic Journal (JDM), Indonesian Mathematics Society (Indoms J.M.E). Thesis and dissertation publications are obtained through manual searches on library and university repository websites. Search results found 119 studies that examine the application of mathematical software in learning mathematics in Indonesia.

\section{Inclusion Criteria}

The studies included in this analysis were selected from experimental and quasiexperimental studies comparing the achievements of studies taught using mathematical software, and students taught with conventional approaches. Studies included in limited synthesis were conducted in Indonesia in the past decade (2011-2019). Statistics that did not show mean, standard deviation, and sample size were not included in this study. Based on the inclusion criteria, a total of 51 studies were included in this study. However, because more than one experimental or control group was used in several studies, 64 comparisons of data were examined.

\section{Coding Data}

The instrument in this meta-analysis is carried out with a coding category sheet. The coding form is made following the predetermined characteristics of the researcher's name, year of study, research class, sample size, and type of mathematical software used. In addition, the coding form is also equipped with a sample size of the two groups, the average, and the standard deviation values. This form of coding was developed to improve reliability in the suitability of the studies involved. For this reason, the two encoders fill out the encoding form separately and then compare. No differences were found between the two forms coded by the researchers. Thus, the data entered in this meta-analysis study is without error. Table 1 shows the information about the study. 
Table 1

Information About the Study

\begin{tabular}{|c|c|c|}
\hline Characteristics & & $\mathrm{f}$ \\
\hline \multirow{3}{*}{$\begin{array}{l}\text { The year of the study was } \\
\text { conducted }\end{array}$} & $2011-2013$ & 9 \\
\hline & $2014-2016$ & 27 \\
\hline & $2017-2019$ & 28 \\
\hline \multirow[t]{3}{*}{ Class } & $4-9$ & 31 \\
\hline & High school & 22 \\
\hline & College & 11 \\
\hline \multirow[t]{2}{*}{ Sample Size } & $1-31$ & 33 \\
\hline & 32 and over & 31 \\
\hline \multirow[t]{8}{*}{ Software type } & Algebrator & 3 \\
\hline & Cabri & 7 \\
\hline & Game Adobe Flash CS 4.0 & 2 \\
\hline & Geo sketchpad & 2 \\
\hline & Geogebra & 33 \\
\hline & Maple & 6 \\
\hline & Microsoft Mathematical & 4 \\
\hline & Wingeom & 7 \\
\hline
\end{tabular}

\section{Reliability Test}

The most important criticism that is common in relation to meta-analysis studies is subjective publication. To determine publication bias, funnel plots, and Rosenthal's Fail-safe N (FSN) statistical are examined. There is no bias if the effect size of the study shows a symmetrical distribution around the overall effect size in the funnel plot (Borenstein et al., 2009). Alternatively, the results are resistant to publication bias if the value of the FSN as a result of an $\mathrm{N}$-failure statistic is greater than the number of studies observed (Rosenthal, 1991). Figure 1 presents a funnel chart obtained in the study.

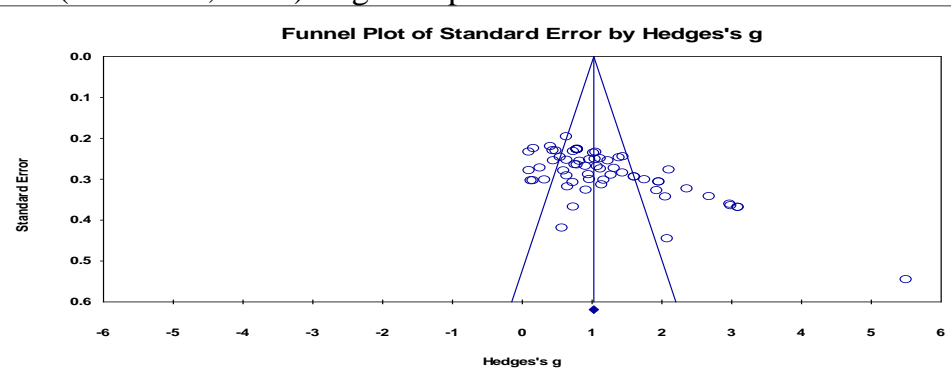

Figure 1

Funnel Plot Related to the Effect Sizes of the Studies Included in the Meta-Analysis

When Figure 1 is examined, it appears that the effect size is spread almost symmetrically in the center of the funnel plot, and on the left and right sides of the vertical line shows the size of the combined effect. Because the distribution does not appear to be fully symmetrical, the Rosenthal FSN statistics are helped to determine the probability of publication bias. Statistical information is given in Table 2. 
Table 2

Rosenthal's FSN Statistics Results

\begin{tabular}{ll}
\hline Bias Condition & \\
\hline The z value for observed studies & 31.77520 \\
The P-value for observed studies & 0.00000 \\
Alpha & 0.05 \\
Tails & 2 \\
The z value for Alpha & 1.95996 \\
Number of Observed Studies & 64 \\
FSN & 6758 \\
\hline
\end{tabular}

As shown in Table 2, the value of $\mathrm{N}$ (FSN) calculated as 6758 is greater than the number of studies observed i.e., 64. Thus it is stated that the results of this meta-analysis are reliable.

\section{Statistic Analysis}

Calculation of average effect size and hypothesis testing using CMA software. The effect size used is Hedge's g. Interpretation of effect sizes, using a classification developed by (Thalheimer \& Cook, 2002), namely:
-0.15-0.15: no level;
0.15-0.40: low level;
$0.40-0.75$ : moderate level;
0.75 -1.10: high level;
1.10 -1.45: very high level;
1.45 or higher: a very good level.

CMA provides an average effect size with confidence intervals for each class of variables as well as homogeneity between groups, namely the $\mathrm{Qb}$ value. As a result of calculations, when the effect size is statistically heterogeneous $(\mathrm{Qb}>\chi 2.95 ; \mathrm{p}<0.05)$, the hypothesis on the effect size homogeneity is rejected (Demir \& Başol, 2014). Rejecting $\mathrm{Qb}$ implies that the effect sizes of groups of variables may not measure the same population parameters (Borenstein et al., 2009). In other words, there is a statistically significant difference in the average effect size for each variable class.

\section{FINDINGS}

\section{Research Findings Concerning the First Sub-Question of the Study}

The first objective of this research is to determine the overall effectiveness of learning using mathematical software on students' mathematical abilities. Based on calculations using CMA software as a whole, the effect sizes are obtained, the confidence interval limits of each are presented in Table 3, which is exported from the following CMA outputs: 
Table 3

Combined Effect Sizes and Confidence Intervals

\begin{tabular}{|c|c|c|c|c|c|}
\hline \multirow[b]{2}{*}{ Author } & \multirow[b]{2}{*}{ Effect Size } & \multicolumn{2}{|c|}{ Confidence Interval } & \multirow{2}{*}{$\begin{array}{l}\text {-Study Weight } \\
\text { (Fixed Effects) }\end{array}$} & \multirow{2}{*}{$\begin{array}{l}\text { Study Weight } \\
\text { Random Effects) }\end{array}$} \\
\hline & & $\begin{array}{l}\text { ower } \\
\text { mit }\end{array}$ & Upper limit & & \\
\hline $\begin{array}{l}\text { Abduh \& } \\
\text { Sutarto(2012) }\end{array}$ & 0.83 & 0.33 & 1.34 & 15.2793 & 1.9697 \\
\hline Aisyah(2015) & 1.27 & 0.72 & 1.87 & 11.9129 & 1.9005 \\
\hline Anggroratri a (2014) & 0.32 & -0.27 & 0.93 & 11.0025 & 1.8757 \\
\hline Anggroratri b (2014) & 0.16 & -0.45 & 0.76 & 10.8737 & 1.8719 \\
\hline Annajmi a(2016) & 2.10 & 1.58 & 2.67 & 13.0343 & 1.9269 \\
\hline Annajmi b(2016) & 1.02 & 0.57 & 1.50 & 17.9881 & 2.0087 \\
\hline Atikasari et al (2013) & 0.97 & 0.48 & 1.48 & 15.7360 & 1.9771 \\
\hline Bernard a (2015) & 0.41 & -0.02 & 0.85 & 20.7016 & 2.0386 \\
\hline Bernard b (2015) & 0.79 & 0.35 & 1.25 & 19.5730 & 2.0270 \\
\hline Darmono et al (2019) & 0.95 & 0.39 & 1.54 & 12.0038 & 1.9028 \\
\hline Desniarti Siti (2018) & 0.92 & 0.28 & 1.59 & 9.3856 & 1.8222 \\
\hline $\begin{array}{l}\text { Senjayawati, et al } \\
\text { (2018) }\end{array}$ & 1.08 & 0.56 & 1.62 & 13.8404 & 1.9437 \\
\hline Erana, et al (2018) & 3.09 & 2.40 & 3.86 & 7.3717 & 1.7304 \\
\hline Farihah (2015) & 1.32 & 0.79 & 1.88 & 13.4076 & 1.9349 \\
\hline $\begin{array}{l}\text { Fitra \& Sitorusn } \\
\text { (2019) }\end{array}$ & 0.97 & 0.38 & 1.58 & 11.0708 & 1.8777 \\
\hline $\begin{array}{l}\text { Fitra \& Syahputra } \\
\text { (2018) }\end{array}$ & 0.79 & 0.27 & 1.32 & 14.2611 & 1.9518 \\
\hline Habinuddin (2018) & 0.63 & 0.25 & 1.03 & 26.0551 & 2.0807 \\
\hline $\begin{array}{l}\text { Haris \& Rahman } \\
\text { (2018) }\end{array}$ & 1.05 & 0.56 & 1.55 & 15.9190 & 1.9800 \\
\hline Hendriana (2019) & 1.23 & 0.74 & 1.75 & 15.4123 & 1.9719 \\
\hline $\begin{array}{l}\text { Hindriyanto, et al } \\
\text { (2018) }\end{array}$ & 0.45 & -0.05 & 0.96 & 15.4345 & 1.9723 \\
\hline Ikhsanudin a (2014) & 1.61 & 1.05 & 2.21 & 11.5598 & 1.8913 \\
\hline Ikhsanudin b (2014) & 0.76 & 0.24 & 1.29 & 14.3427 & 1.9533 \\
\hline Indra Jaya (2014) & 1.05 & 0.60 & 1.53 & 18.2989 & 2.0125 \\
\hline Jelatu, et al a (2018) & 1.12 & 0.59 & 1.68 & 13.2592 & 1.9318 \\
\hline Jelatu, et al b (2018) & 0.73 & 0.01 & 1.50 & 7.3961 & 1.7318 \\
\hline Jelatu, et al c (2018) & 2.08 & 1.24 & 3.03 & 5.0431 & 1.5612 \\
\hline Khotimah a (2018) & 0.79 & 0.35 & 1.25 & 19.3603 & 2.0247 \\
\hline Khotimah b (2018) & 0.79 & 0.35 & 1.25 & 19.3603 & 2.0247 \\
\hline Khotimah c (2018) & 0.79 & 0.35 & 1.25 & 19.3603 & 2.0247 \\
\hline Khotimah d (2018) & 0.79 & 0.35 & 1.25 & 19.3603 & 2.0247 \\
\hline Kusumah et al (2014) & 0.65 & 0.03 & 1.30 & 9.8647 & 1.8396 \\
\hline Netriwati (2013) & 0.73 & 0.13 & 1.35 & 10.5577 & 1.8624 \\
\hline $\begin{array}{l}\text { Nuraeni \& Rosyid } \\
\text { (2019) }\end{array}$ & 0.64 & 0.15 & 1.15 & 15.5757 & 1.9746 \\
\hline $\begin{array}{l}\text { Nurhidayah, et al } \\
\text { (2018) }\end{array}$ & 1.96 & 1.38 & 2.59 & 10.6568 & 1.8654 \\
\hline Nuriadin (2015) & 2.05 & 1.40 & 2.77 & 8.4997 & 1.7861 \\
\hline $\begin{array}{l}\text { Oktaviyanthi, et al } \\
\text { (2014) }\end{array}$ & 0.57 & -0.26 & 1.45 & 5.6917 & 1.6183 \\
\hline Priyono, et al (2015) & 0.10 & -0.36 & 0.56 & 18.3716 & 2.0134 \\
\hline Pustari (2013) & 0.26 & -0.28 & 0.80 & 13.4933 & 1.9367 \\
\hline Raditya (2016) & 0.64 & 0.07 & 1.23 & 11.7781 & 1.8970 \\
\hline Ramadani, et al (2016) & 0.44 & -0.01 & 0.90 & 18.9206 & 2.0198 \\
\hline
\end{tabular}

International Journal of Instruction, October $2020 \bullet$ Vol.13, No.4 


\begin{tabular}{|c|c|c|c|c|c|}
\hline Ramdani (2017) & 0.48 & 0.03 & 0.95 & 18.8287 & 2.0188 \\
\hline Risnawati (2012) & 1.17 & 0.59 & 1.79 & 10.9635 & 1.8746 \\
\hline Rosyid (2018) & 2.99 & 2.30 & 3.75 & 7.5256 & 1.7388 \\
\hline Septian (2016) & 1.96 & 1.38 & 2.59 & 10.6489 & 1.8652 \\
\hline Setyani, et al (2015) & 0.10 & -0.45 & 0.66 & 12.8857 & 1.9237 \\
\hline Siswanto et al (2017) & 1.61 & 1.04 & 2.21 & 11.5651 & 1.8914 \\
\hline Sumarni, et al (2017) & 5.50 & 4.49 & 6.65 & 3.3622 & 1.3520 \\
\hline $\begin{array}{l}\text { Supriadi, et al a } \\
\text { (2014) }\end{array}$ & 2.68 & 2.03 & 3.39 & 8.5399 & 1.7878 \\
\hline $\begin{array}{l}\text { Supriadi, et al b } \\
(2014)\end{array}$ & 3.09 & 2.40 & 3.86 & 7.3628 & 1.7299 \\
\hline $\begin{array}{l}\text { Supriadi, et al c } \\
\text { (2014) }\end{array}$ & 2.97 & 2.30 & 3.73 & 7.6843 & 1.7471 \\
\hline $\begin{array}{l}\text { Supriadi, et al d } \\
\text { (2014) }\end{array}$ & 2.36 & 1.75 & 3.03 & 9.5631 & 1.8288 \\
\hline Surya (2018) & 0.16 & -0.28 & 0.61 & 19.8240 & 2.0297 \\
\hline Suryamiharja a (2017) & 0.73 & 0.28 & 1.20 & 18.6003 & 2.0161 \\
\hline $\begin{array}{l}\text { Sya'diah \& Safitri } \\
\text { (2014) }\end{array}$ & 0.55 & 0.06 & 1.04 & 16.5135 & 1.9889 \\
\hline Syamsuduha (2011) & 0.91 & 0.39 & 1.45 & 13.9238 & 1.9453 \\
\hline Umbara, et al (2018) & 1.44 & 0.97 & 1.94 & 16.6990 & 1.9915 \\
\hline $\begin{array}{l}\text { Usman \& Halim } \\
\text { (2017) }\end{array}$ & 1.12 & 0.64 & 1.62 & 16.0735 & 1.9823 \\
\hline Yulian (2016) & 1.39 & 0.91 & 1.89 & 16.3691 & 1.9868 \\
\hline Paradesa et al (2017) & 1.44 & 0.89 & 2.02 & 12.3580 & 1.9115 \\
\hline Indrajaya et al (2014) & 0.59 & 0.05 & 1.16 & 12.8166 & 1.9221 \\
\hline $\begin{array}{l}\text { Tamur \& Kurnila } \\
\text { (2013) }\end{array}$ & 1.14 & 0.53 & 1.78 & 10.1753 & 1.8501 \\
\hline Sari (2013) & 0.13 & -0.48 & 0.74 & 10.8599 & 1.8715 \\
\hline Nurhayati (2013) & 1.75 & 1.18 & 2.38 & 11.0383 & 1.8768 \\
\hline Sari at. all (2017) & 1.93 & 1.31 & 2.61 & 9.3211 & 1.8198 \\
\hline
\end{tabular}

Based on Table 3, the overall range of effect sizes (ES) is from -0.0 .48 to 6.65 with a 95\% confidence limit. Referring to the classification of Thalheimer and Cook (2002), sixteen studies can be examined at a very good level; ten studies have very high rates; seventeen studies have a high level; fourteen studies have medium level; the other four have a low leel. Only three studies did not have a level. Table 4 shows a comparison of meta-analysis results according to the effect model.

Table 4

Comparison of Meta-Analysis Results According to the Effect Model

\begin{tabular}{|c|c|c|c|c|c|c|c|c|}
\hline \multirow[b]{2}{*}{ Model } & \multirow[b]{2}{*}{$\mathrm{n}$} & \multirow[b]{2}{*}{$\mathrm{Z}$} & \multirow[b]{2}{*}{$\mathrm{P}$} & \multirow[b]{2}{*}{ Q } & \multicolumn{2}{|l|}{ I-squared } & \multicolumn{2}{|c|}{ Zonfidence Interval } \\
\hline & & & & & $\begin{array}{l}\text { Table } \\
\text { value } \\
(\mathrm{p}=0.05)\end{array}$ & $\begin{array}{r}\text { Effect } \\
\text { Size }\end{array}$ & $\begin{array}{l}\text {-ower } \\
\text { imit }\end{array}$ & $\begin{array}{l}\text { Jpper } \\
\text { imit }\end{array}$ \\
\hline Fixed effects model & 64 & 9.955 & 0 & 34.344 & 85.495 & 1.025 & 1.957 & .091 \\
\hline Random effects model & 64 & 2.818 & 0 & .34.344 & 85.495 & 1.261 & 1.984 & .339 \\
\hline
\end{tabular}

When Table 4 is examined, it appears that according to the fixed-effect model, the lower limit of the $95 \%$ confidence interval is 0.957 , and the upper limit is 1.091 . The average effect size is calculated at 1.025. This effect size is accepted at a very high level, according to Thalheimer and Cook (2002). As a result of calculating the $\mathrm{z}$ test to 
determine statistical significance, the $\mathrm{z}$ score was found to be 29.955. This result can be said to be statistically significant at the level of $\mathrm{p}=0.000$. Homogeneity test results revealed that the $\mathrm{Q}$ value was 208.425. This value was found to be greater than 82.528 with degrees of freedom 63 and $\mathrm{p}=0.05$ in Table $\chi 2$. Thus, the distribution of effect sizes was found to be heterogeneous. Because the homogeneity test results are higher than the critical value, the random-effects model is evaluated.

According to the random effect model in Table 4, the $95 \%$ confidence interval has a lower limit of 0.984 and an upper limit of 1.339 , and the average effect size is calculated at 1.261. According to Thalheimer and Cook (2002), the size of this effect is accepted at a very high level. As a result of calculating the $\mathrm{z}$ test to determine statistical significance, the $\mathrm{z}$ score was found to be 12.818 . This result can be said to be statistically significant at the level of $p=0.000$. Based on the I-square value, then $85 \%$ of the variants observed between studies were due to real differences in effect size. Only about $15 \%$ of the observed variants are expected based on random errors. Thus it can be stated that the use of mathematical software produces a measure of the effect of mathematical ability that is greater than conventional approaches.

\section{Research Findings Regarding Second Sub-Question}

Findings related to the second question are shown in Table 5.

Table 5

Findings Related to the Second Question

\begin{tabular}{|c|c|c|c|c|c|c|}
\hline \multirow[t]{2}{*}{ Year } & \multirow[t]{2}{*}{$\mathrm{n}$} & \multirow{2}{*}{$\begin{array}{l}\text { Hedge's } \\
\mathrm{g}\end{array}$} & \multicolumn{2}{|c|}{$\% 95$ Confidence Interval } & \multicolumn{2}{|c|}{ Heterogeneity Test } \\
\hline & & & Lower limit & Upper limit & Qb value & $\mathrm{p}$ \\
\hline 2011-2013 & 9 & 0.884 & 0.572 & 1.065 & & \\
\hline 2014-2016 & 27 & 1.148 & 0.837 & 1.458 & & \\
\hline 2017-2019 & 28 & 1.303 & 1.036 & 1.571 & & \\
\hline Fixed effect model & & & & & 34.429 & 0.025 \\
\hline Random effect model & & & & & 6.039 & 0.025 \\
\hline
\end{tabular}

According to the results of the analysis given in Table 5, the effect size of the studies conducted between 2011 and 2013 was 0.884 ; between 2014 and 2016 is 1.148 , and between 2016 and 2019 is 1.303 . The Q statistical value obtained as a result of the homogeneity test was calculated to be 34.429 . Because this value is greater than 5.99 at $95 \%$ confidence intervals from the 0.05 significance level, the random-effects model was evaluated. Thus, it can be said that the distribution has a heterogeneous structure. As a result of the analysis made, it can be said that the measure of the effect of mathematical ability from the use of mathematical software between different study groups was reviewed from the year the study was conducted $(\mathrm{Qb}=6.039 ; \mathrm{p}=0.025)$.

\section{Research Findings Regarding Third Sub-Question}

Findings related to the third question are shown in Table 6. 
Table 6

Findings Related to the Third Question

\begin{tabular}{lllllll}
\hline Class Level & $\mathrm{n}$ & Hedge's & \multicolumn{2}{c}{ \%95 Confidence Interval } & \multicolumn{2}{c}{ Heterogeneity Test } \\
\cline { 4 - 7 } & & $\mathrm{g}$ & Lower limit & Upper limit & Qb value & $\mathrm{p}$ \\
\hline IV-IX & 31 & 1.091 & 0.994 & 1.189 & & \\
High School & 22 & 1.075 & 0.815 & 1.042 & & \\
College & 11 & 1.385 & 0.823 & 1.947 & & 0.027 \\
\hline Fixed effect model & & & & & 7.258 & 0.027 \\
Random effect model & & & & & 2.487 & \\
\hline
\end{tabular}

When Table 6 was examined, the effect size of the study's mathematical ability conducted between class IV and class IX was 1.091; high school is 1.075, and college is 1.385. The statistical value of $\mathrm{Q}$ obtained as a result of the homogeneity test was calculated to be 7.259. Because this value is greater than the 5.99 value at a $95 \%$ confidence interval from the 0.05 significance level, the random-effects model was evaluated. Thus, it can be said that the distribution has a heterogeneous structure. As a result of the analysis made, it can be said that the size of the effect of mathematical ability from the use of mathematical software between study groups did not differ in terms of the research class $(\mathrm{Qb}=2.487 ; \mathrm{p}=0.027)$.

\section{Research Findings Regarding Fourth Sub-Question}

Findings related to the fourth question are shown in Table 7.

Table 7

Findings Related to the Fourth Question

\begin{tabular}{lllllll}
\hline Sample size & $\mathrm{n}$ & \multirow{2}{*}{\begin{tabular}{l} 
Hedge's \\
\cline { 3 - 6 }
\end{tabular}} & $\mathrm{g}$ & \%95 Confidence Interval & \multicolumn{2}{l}{ Heterogeneity Test } \\
\hline $1-31$ & 33 & 1.130 & 0.894 & 1.365 & & \\
32 and over & 31 & 1.011 & 0.922 & 1.502 & & \\
\hline Fixed effect model & & & & & 39.859 & 0.000 \\
Random effect model & & & & & 1.000 & 0.000 \\
\hline
\end{tabular}

When Table 7 was examined, the effect size of the study's mathematical ability with a sample size less than or equal to 31 was 1.130; The effect size of the study's mathematical ability with a sample size of more than or equal to 32 is 1.011 . The statistical value of Q obtained as a result of the homogeneity test was calculated to be 39.859. Because this value is greater than the value of 3.841 at a $95 \%$ confidence interval from the 0.05 significance level, the random-effects model was evaluated. Based on the random-effects model, it can be said that the distribution has a heterogeneous structure. As a result of the analysis made, it was concluded that the size of the effect of mathematical ability from the use of mathematical software between study groups did not differ in terms of sample size $(\mathrm{Qb}=1.000 ; \mathrm{p}=0.000)$. 


\section{Research Findings Regarding Fourth Sub-Question}

Findings related to the fifth question are shown in Table 8.

Table 8

Findings Related to the Fifth Question

\begin{tabular}{|c|c|c|c|c|c|c|}
\hline \multirow[t]{2}{*}{ Software type } & \multirow[t]{2}{*}{$\mathrm{n}$} & \multirow{2}{*}{$\begin{array}{l}\text { Hedge's } \\
\mathrm{g}\end{array}$} & \multicolumn{2}{|c|}{$\% 95$ Confidence Interval } & \multicolumn{2}{|c|}{ Heterogeneity Test } \\
\hline & & & Lower limit & Upper limit & Qb value & $\mathrm{p}$ \\
\hline Algebrator & 3 & 1.217 & 0.955 & 1.560 & & \\
\hline Cabri & 7 & 0.960 & 0.565 & 1. 355 & & \\
\hline Game Adobe Flash & 2 & 0.602 & 0.220 & 0.983 & & \\
\hline Geo sketchpad & 2 & 1.361 & 0.941 & 1.780 & & \\
\hline Geogebra & $\begin{array}{l}3 \\
3\end{array}$ & 1.413 & 1.109 & 1.717 & & \\
\hline Maple & 6 & 1.032 & 0.808 & 1.456 & & \\
\hline Microsoft Math & 4 & 0.608 & 0.304 & 0.919 & & \\
\hline Wingeom & 7 & 0.786 & 0.959 & 1.328 & & \\
\hline Fixed effect model & & & & & 73.021 & 0.000 \\
\hline Random effect mode & & & & & 16.079 & 0.000 \\
\hline
\end{tabular}

When Table 8 was examined, the effect size of the study's mathematical ability using Algebrator software was 1.217; Cabri software is 0.960; Adobe Flash game software is 0.602 ; geo sketchpad software is 1.361; GeoGebra software is 1.413; Maple software is 1.032; Microsoft mathematical software is 0.608 , and Wingeom software is 0.786 . The statistical value of Q obtained as a result of the homogeneity test was calculated to be 73.021. Because this value is greater than the value of 14.07 at the $95 \%$ confidence interval from the 0.05 significance level, the random-effects model was evaluated. Based on the random-effects model, it can be said that the distribution has a heterogeneous structure. As a result of the analysis made, it was concluded that the measure of the effect of mathematical ability from the use of mathematical software between different study groups in terms of the type of mathematical software used $(\mathrm{Qb}=$ 16.079; $\mathrm{p}=0.000)$.

\section{DISCUSSION}

This study synthesized the results of 64 effect sizes from 51 studies. According to the random model, the effect size of 64 studies of 1.261 shows that learning using mathematical software has a very strong influence on students' mathematical abilities compared to conventional learning. The effect size of 1.261 can be interpreted that the average student exposed to learning using mathematical software exceeds the mathematical ability of $88 \%$ of students in conventional classes that were initially equivalent. This finding can also be interpreted that, students shift from the 50th percentile to the 88th percentile in mathematical abilities when learning using mathematical software is applied. In addition, the effect size is 1.261 if it is confirmed by the interpretation table developed by Coe (2002), so it can be stated that the average student is ranked 13th in the experimental group, equivalent to students ranked 3rd in the control group. 
This finding is consistent with research by Tumangkeng, Yusmin \& Hartoyo (2018). The researchers found an effect size of 0.950 when they synthesized from 33 studies comparing the effectiveness of using mathematical media to student mathematics learning outcomes. Another study conducted by Chan and Leung (2014) compared the effectiveness of DGS-based teaching on students' mathematical achievement by synthesizing 587 primary studies. They found the overall effect size of DGS-based instruction on mathematical achievement was 1.02. In addition, Higgins, HuscroftD'Angelo, \& Crawford (2019) conducted a meta-analysis of the use of technology media in mathematics learning with 24 articles. The researchers found that the overall impact of technology was significant on student achievement, motivation, and attitude, but varied based on the aspect of the intervention being examined. Other studies that appear to be somewhat different were conducted by Turgut \& Turgut (2018). They conducted a meta-analysis of the effect of visualization on mathematical achievements, including using computers. The average effect size value calculated according to the random effect model was found as 0.811 , with a standard error of 0.076 . The positivity of the effect size indicates that the implication effect supports the experimental group but has a moderate effect on mathematical achievement.

This meta-analysis detects the effect size of mathematical ability from the use of mathematical software between study groups in terms of various research characteristics. The analysis showed a significant difference in the use of software but not significant in the year when the study was conducted. According to the random-effects model, the most effective effect size when mathematical software is used is geogebra, which is 1.413, summarized from 33 studies. However, this result is very different from the findings from Tumangkeng, Yusmin \& Hartoyo (2018), which show the size of the effect of the use of geogebra of 0.43 , which is summarized from 1 study. This contrasting contrast raises new hypotheses that meta-analysis studies that only show the effect size of a few studies may not explain the actual conditions.

Furthermore, the size of the effect with a moderate level is the use of games that is equal to 0.602 , which is summarized from 2 studies. These results are almost in line with findings from Turgut \& Dogan Temur (2017), who examined the effects of using games in the process of teaching mathematics in academic achievement in Turkey examined by meta-analysis methods. The average effect size value is 0.792 , with a standard error of 0.077 , which is calculated by the random-effects model. This finding confuses our understanding that games are very important in learning.

Judging from the year when the research was conducted, it produced a different effect size, but it was not significant. The largest effect size is a study conducted from 2016 to 2019 , which is 1.303 . These results indicate that from year to year, the size of the effect of mathematical ability from the use of mathematical software is increasing. Based on the sample size, it was found that the effect sizes of the two groups did not differ. But there is a tendency to measure the effect of the mathematical ability of groups less than or equal to 31 greater than groups of more than or equal to 32. Furthermore, in terms of the class of research conducted, it was found that there were no significant differences in effect sizes between groups. All three groups achieved very high effect sizes according 
to the Thalheimer \& Cook (2002) category. Thus it can be stated that the use of mathematical software is recommended for all levels of education.

\section{CONCLUSIONS}

As a result of the study, the overall effect size was 1.162, with a standard error of 0.091 according to the random-effects model. These results indicate that the average student who is ranked 13th in the experimental group is equivalent to those who are ranked 4th in the control group. The size of the effect shows that using mathematical software in mathematics classrooms is very effective in improving students' mathematical abilities. An investigation of effectiveness based on study characteristics revealed that the use of mathematical software was more effective in certain conditions. This analysis, for example, revealed that there were no significant differences in the use of mathematical software in terms of sample size. However, it appears that the sample effect size that is less than or equal to 31 is greater than the sample effect size that is more than or equal to 32. Providing classrooms with a number of students less than or equal to 31 will be useful and recommended for the level of effectiveness higher. This meta-analysis also revealed that the latest study group showed an increasingly large effect size. Based on the mathematical software used, this meta-analysis also revealed that geogebra math software was more effective than other mathematical software. This analysis also revealed that the use of mathematical software between study groups did not differ in terms of the research class. Mathematical software can be used in a variety of mathematics classes.

\section{LIMITATIONS}

Although this analysis shows that the use of mathematical software has a very large effect on mathematical ability, this finding is only based on studies that allow the calculation of effect sizes using CMA. There are still many similar studies that have not been analyzed because it is not possible to do calculations. In addition, this study only examined four study characteristics, namely the year when the study was conducted, the class conducted the study, the sample size, and the type of software used. This study has not yet reached the variables based on the duration of the treatment, the research location, for example, based on the division of the regions of western, central, and eastern Indonesia and the material taught. As a result, the conclusions in this study do not mean to describe the overall effectiveness of using mathematical software. Therefore in the future, researchers are advised to conduct research by analyzing more studies so they can reach the characteristics needed.

\section{ACKNOWLEDGMENTS}

The author thanks the Santu Paulus Ruteng Foundation for funding this research. The same thanks go to Prof. James J Lindsay, who has provided many very important references to this research via email. 


\section{REFERENCES}

Artigue, M. (2002). Learning mathematics in a CAS environment: The genesis of a reflection about instrumentation and the dialectics between technical and conceptual work. CAME Symposium, 1, 1-16. https://doi.org/10.1023/A.

Aungamuthu, Y. (2013). Towards a responsive pedagogy: Using ICT as a tool to engage access students' academic identities in mathematics. Alternation, 8, 66-85.

Berežný, Š. (2015). What software to use in the teaching of mathematical subjects? Acta Didactica Napocensia, 8(1).

Borenstein, M., \& Hedges, L. V., Higgins, P. T., \& Rothstein, H. R. (2009). Introduction to meta-analysis. John Wiley \& Sons.

Cingi, C. C. (2013). Computer aided education. Procedia - Social and Behavioral Sciences, 103, 220-229. https://doi.org/10.1016/j.sbspro.2013.10.329.

Cleophas, T. J., \& Zwinderman, A. H. (2017). Modern meta-analysis. Springer

Coe, R. (2002). It's the Effect Size , Stupid: What effect size is and it is important. Paper presented at the Annual Conference of the British Educational Research Association, University of Exeter, England, 12-14 September 2002.

Chan, K. K., \& Leung, S. W. (2014). Dynamic geometry software improves mathematical achievement: Systematic review and meta-analysis. Journal of Educational Computing Research, 51(3), 311-325. https://doi.org/10.2190/EC.51.3.c.

Cohen, J. (1988). Statistical power analysis for the behavioral sciences. Lawrence Erlbaum Associates.

Colado, A. Z., Vázquez, R. I. A., \& Patrón, D. E. R. (2017). Evaluation of using mathematics educational software for the learning of first-year primary school students. Education Sciences, 7(79), 1-12. https://doi.org/10.3390/educsci7040079.

Demir, S., \& Başol, G. (2014). Effectiveness of computer-assisted mathematics education (CAME) over academic achievement: A meta-analysis study. Kuram ve Uygulamada Egitim Bilimleri, 14(5), 2026-2035. https://doi.org/10.12738/estp.2014.5.2311.

Ellis, P. D. (2010). The essential guide to effect sizes. Cambridge University Press.

Foster, M. E., \& Anthony, J. L. (2016). Improving mathematics learning of kindergarten students through computer-assisted instruction. J for Res in Mathematics Education, 47(3), 206-232. https://doi.org/10.5951/jresematheduc.47.3.0206.

Foster, M. E., Anthony, J. L., Clements, D. H., \& Sarama, J. (2016). Improving mathematics learning of kindergarten students through computer-assisted instruction. 
Journal for Research in Mathematics Education, 47(3), 206-232. https://doi.org/10.5951/jresematheduc.47.3.0206.

Glass, G. V. (1976). Primary, secondary, and meta-analysis of research. Educational Researcher, 5(10), 3-8. https://doi.org/10.3102/0013189x005010003.

Hartsell, T., Herron, S., Fang, H., \& Rathod, A. (2009). Effectiveness of professional development in teaching mathematics and technology applications. 2(1), 53-64. https://doi.org/10.18785/jetde.0201.04

Hedges, L. V, \& Olkin, I. (1985). Statistical methods in meta-analysis. Journal of Educational Statistics, 13(1), 75-78. https://doi.org/10.2307/1164953.

Herawati, L., Studi, P., Matematika, P., \& Siliwangi, U. (2017). Peningkatan kemampuan koneksi matematik peserta didik menggunakan model problem based learning ( PBL ) dengan berbantuan Software Geogebra [Improving students' mathematical representation ability by using problem-based learning (PBL) models assisted by Geogebra software media]. Jurnal Penelitian Pendidikan Dan Pengajaran Matematika, 3(1), 39-44.

Higgins, S., \& Katsipataki, M. (2015). Evidence from meta-analysis about parental involvement in education which supports their children's learning. Journal of Children's Services, 10(3), 280-290. https://doi.org/10.1108/JCS-02-2015-0009.

Higgins, K., Huscroft-D’Angelo, J., \& Crawford, L. (2019). Effects of technology in mathematics on achievement, motivation, and attitude: A meta-analysis. Journal of Educational Computing Research, 57(2), 283-319. https://doi.org/10.1177/0735633117748416.

Horton, R. M., Storm, J., \& Leonard, W. H. (2004). The graphing calculator as an aid to teaching algebra. Contemporary Issues in Technology and Teacher Edu, 4(2), 152 -162.

Hunter, J. E., \& Schmidt, F. L. (2004). Methods of meta analysis: Correcting error and bias in research finding. SAGE Publications.

Jelatu, S., Sariyasa, \& Ardana, I. M. (2018). Effect of GeoGebra-aided REACT strategy on understanding of geometry concepts. International Journal of Instruction, 11(4), 325-336. https://doi.org/10.12973/iji.2018.11421a.

Karakuş, F., \& Aydin, B. (2017). The effects of computer algebra system on undergraduate students' spatial visualization skills in a calculus course. Malaysian Online Journal of Educational Technology, 5(3), 54-69.

Kilicman, A., Hassan, M. A., \& Husain, S. K. S. (2010). Teaching and learning using mathematics software "the new challenge". Procedia-Social and Behavioral Sciences, 8 , 613-619. https://doi.org/10.1016/j.sbspro.2010.12.085. 
Kulik, J. A., Bangert, R. L., \& Williams, G. W. (1983). Effects of computer-based teaching on secondary school students. Journal of Educational Psychology, 75(1), 1926. https://doi.org/10.1037/0022-0663.75.1.19.

Kumar, A., \& Kumaresan, S. (2008). Use of mathematical software for teaching and learning mathematics. ICME 11 Proceedings, 373-388.

Lavicza, Z. (2010). Integrating technology into mathematics teaching at the university level. ZDM Mathemiatics Edu, 42,105-119. https://doi.org/10.1007/s11858-009-0225-1.

Nuraeni, Z., \& Rosyid, A. (2019). Pengaruh Model Pembelajaran Index Card Match (ICM) dengan Problem Posing Berbantuan Software MATLAB terhadap Kemampuan Pemecahan Masalah [The Effect of Index Card Match (ICM) Learning Model with MATLAB Software Assisted Problem Posing on Problem Solving Ability]. Jurnal Elemen, 5(1), 12. https://doi.org/10.29408/jel.v5i1.710.

Ochkov, V., \& Bogomolova, E. P. (2015). Teaching mathematics with mathematical software. Journal of Humanistic Mathematics, 5(1), 265-285. https://doi.org/10.5642/jhummath.201501.15.

Pierce, R., \& Stacey, K. (2004). A framework for monitoring progress and planning teaching towards the effective use of computer algebra systems. Int J of Comp for Math Learning, 9, 59-93. https://doi.org/10.1023/B:IJCO.0000038246.98119.14.

Pigott, T. D. (2012). Advances in meta-analysis. New York: Springer.

Ramadhani. (2017). Perbedaan Peningkatan Self Efficacy Matematis Antara Siswa Yang Mendapat Pembelajaran Penemuan Terbimbing Berbantuan Geogebra Dengan Tanpa Berbantuan Geogebra Di Smpn 22 Medan [Difference Between Increased Mathematical Self Efficacy Between Students Who Get Geogebra Assisted Guided Discovery Learning Without Geogebra Assisted In Smpn 22 Medan]. Jurnal Pendidikan MIPA, 2(1), 159-165.

Randolph, J. J. (2009). A guide to writing the dissertation literature review in software engineering. Practical Assessment, Research \& Evaluation, 14(13), 1-13.

Rosenthal, R. (1979). The "file drawer problem" and tolerance for null results. Jnl. Jsme, 64(3), 638-641.

Saha, R. A., Ayub, A. F. M., \& Tarmizi, R. A. (2010). The effects of geogebra on mathematics achievement: Enlightening coordinate geometry learning. Procedia Social and Behavioral Sciences, 8, 686-693. https://doi.org/10.1016/j.sbspro.2010.12.095.

Schwarzer, G., Carpenter, J. R., \& Rücker, G. (2015). Small-study effects in metaanalysis. In G. Schwarzer, J. R. Carpenter, \& G. Rücker (Eds.), Meta-analysis with R (pp.101-147). Springer. https://doi.org/10.1007/978-3-319-21416-0_5. 
Setyani, N. (2016). Efektivitas Pembelajaran Matematika Dengan Model CPS Berbantuan Geogebra Ditinjau Dari Prestasi Belajar Dan Kreativitas Siswa Kelas VIII SMP PGRI Tegalsari Kabupaten Purworejo [the effectiveness of mathematics learning with geogebra-assisted cps models in terms of learning achievement and creativity of grade VIII students of PGRI Tegalsari Purworejo Regency]. Jurnal Pendidikan Matematikadan Sains, 5(7).

Shadaan, P., \& Leong, K. E. (2016). Effectiveness of using geogebra on students ' understanding in learning circles. The Malaysian Online Journal of Educational Technology, 1(4).

Shelby, L. B., \& Vaske, J. (2008). Understanding meta-analysis: A review of the methodological literature. Leisure Sciences, 30(2), 96-110. https://doi.org/10.1080/01490400701881366.

Siddaway, A. P., Wood, A. M., \& Hedges, L. V. (2019). How to do a systematic review: A best practice guide for conducting and reporting narrative reviews, meta-analyses, and meta-syntheses. Annual Review of Psychology, 70(1), 747-770. https://doi.org/10.1146/annurev-psych-010418-102803.

Siswanto, R. D., \& Kusumah, Y. S. (2017). Peningkatan Kemampuan Geometri Spasial Siswa Smp Melalui Pembelajaran Inkuiri Terbimbing Berbantuan Geogebra [Improvement of Spatial Geometry Ability of Junior High School Students through Guided Inquiry Learning Assisted by Geogebra]. Jurnal Penelitian Dan Pembelajaran Matematika, 10(1). https://doi.org/10.30870/jppm.v10i1.1196.

Sivakova, D., Kochoska, J., Ristevska, M., \& Gramatkovski, B. (2017). ICT- The educational programs in teaching mathematics. TEM Journal, 6(3), 469-478. https://doi.org/10.18421/TEM63-06.

Supriadi, N., Kusumah, Y. S., Sabandar, J., \& Afgani, J. D. (2014). Developing highorder mathematical thinking competency on hi gh school students' through geo gebraassisted blended learning. Mathematical Theory and Modelling, 4(6), 57-66.

Tatar, E. (2013). The effect of dynamic software on prospective mathematics teachers perceptions regarding information and communication technology. Australian Journal of Teacher Education, 38(12).

Thalheimer, W., \& Cook, S. (2002). How to calculate effec sizes from published research articles: A simplefied methodology. Work-Learning Research. Retrieved from https://pdfs.semanticscholar.org/d7f0/c3a171f

fd6bad4297feeb708a2d79e06da8b.pdf?_ga=2.149295606.1950164162.15681007772068894367.1568100777.

Timmers, C. F., Broek, J. B., \& Berg, S. M. (2013). Motivational beliefs, student effort, and feedback behaviour in computer-based formative assessment. Computers \& Education, 60(1), 25-31. https://doi.org/10.1016/j.compedu.2012.07.007. 
Tomić, M. K. (2013). Mathematical software in croatian mathematics classrooms - A review of geogebra and sketchpad. Croatian Journal of Education, 15(1), 197-208.

Tumangkeng, Y. W., Yusmin, E., \& Hartoyo, A. (2018). Meta Analysis Pengaruh Media Pembelajaran Terhadap Hasil Belajar Matematika Siswa [Meta Analysis of the Effect of Learning Media Against Student Math Learning Outcomes]. Jurnal Pendidikan Dan Pembelajaran Katulistiwa, 10(2), 1-15.

Turgut, S., \& Dogan Temur, Ö. (2017). The effect of game-assisted mathematics education on academic achievement in Turkey: A meta-analysis study. International E-J of Elementary Education, 10(2), 195-206. https://doi.org/10.26822/iejee.2017236115.

Turgut, İ. G., \& Turgut, S. (2018). The effects of visualization on mathematics achievement in reference to thesis studies conducted in Turkey: A meta-analysis. Universal Journal of Educational Research, 6(5), 1094-1106. https://doi.org/10.13189/ujer.2018.060531.

Yesilyurt, M., Dogan, M., \& Acar, S. (2019). The meta-analysis of the effect of computer aided instruction on student attitudes in science and mathematics. Journal of Primary Education, 1(2), 57-69. 